\title{
Comparison of Family Attitudes for 7-12 Year Old Enuretic and Nonenuretic Children
}

\author{
Birgül Vural ${ }^{1}$, Emine Altun Yilmaz ${ }^{2}$

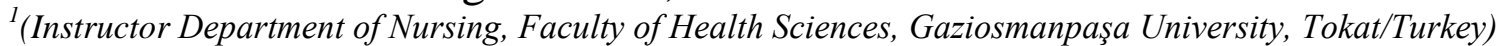 \\ ${ }^{2}$ (Asst. Prof. Dr. Department of Nursing, Faculty of Health Sciences, Cumhuriyet University, Sivas/Turkey)
}

\begin{abstract}
:
Objective: The present study was conducted to compare the family attitudes towards 7-12 year old enuretic and nonenuretic children in provincial center of Tokat.

Method:, The present research was carried out as a descriptive (case-control) study with the mothers of 7-12 year old children receiving education in primary schools operating under Tokat Provincial Directorate of National Education. The sample of the study consists of the mothers of 140 enuretic students (68 girls and 72 boys) and 140 nonenuretic students (68 girls and 72 boys), 280 people in total, selected as the control group. The data was collected using parental attitudes research instrument (PARI) to evaluate the parental attitudes towards child-rearing and family life. Variance analysis, chi-square and Mann Whitney U tests were used in data analysis.

Results: According to the results of the study, "Dimension of marital conflict" was adopted among the mothers of enuretic and nonenuretic children, "marital conflict" attitude was adopted in enuretic group depending on the employment status of mothers, "rejection of the role" attitude was adopted depending on the age of enuresis, "maternal protection" attitude was adopted by all mothers towards their children, and "democratic and rejective" attitude was observed as the parental response towards children. "Overprotection and rejection of the role" was observed based on the gender in the nonenuretic group, "democratic attitude" of mother was observed depending on the number of children, "rejection of the role, marital conflict, and severe discipline" attitudes were observed depending on the educational status of parents, and "marital conflict and severe discipline" attitudes were observed depending on the employment status of mother and family types.

Conclusion: Dimension of marital conflict was found to be higher among the parents with enuretic children compared to those with nonenuretic children. Improving the nursing services in schools with cooperation of teachers and health care teams is recommended as a means to raise the awareness among the parents with enuretic children that the attitude of "marital conflict" has negative impacts on the emotional and social health of children, and as a means for the planning of behavioral modification.
\end{abstract}

Keywords: enuresis, family, attitude

\section{Introduction}

Enuresis is an important problem, commonly encountered in childhood, with significant impacts on children, their families and immediate vicinity. Enuresis is defined as repetitive involuntary nocturnal urination in bed or on clothes at early ages in which the control over the urinary bladder is to be acquired (Ertan and Karaboğa, 2012). The worldwide studies on the subject indicate that enuresis occurs at a rate of $15.5 \%$ at primary school period and at a rate of $2 \%$ in adolescence period (Cendron et al. 1998; Butler et al. 2005). It is reported in the domestic studies that the children at the school age are affected by enuresis at a rate ranging between 10 and 15\% (Ünalan, 2000; Çarman et al., 2003; Dönmez 2004). In a recent research it was reported that, $18 \%$ of the children were suffering enuresis, $75,9 \%$ of the children with enuresis were in $6-8$ age group, and 24,1\% were in 9-12 age group (Kürtüncü and Alkan, 2016).

Several causes have been reported in the etiology of enuresis up to this day. The role of genetics, environmental factors, functional bladder capacity, antidiuretic hormone secretion, trouble in awakening or psychological issues were emphasized as the causes of enuresis Uluocak and Erdemir (2011). The birth of a sibling, low socioeconomic level, school starting age, change of school and parental attitudes were reported as some of the psychosocial factors (Küçük, 2009, Ünalan et al,2000).

In Turkish society, over-monitoring mothering model seems to be commonly adopted among mothers (Hızel, 1990; Genç, 1994). In a research involving the parents of enuretic children, majority of the parents were found to be over-monitoring, anxious; and some were short-tempered and eager to resort to punishment as a coping method (Butler, 1998). In Șahin's research (2000), addressing the family attitudes towards enuresis, $51.6 \%$ of the parents were angry with their children, $29 \%$ were punishing them, $29 \%$ were overlooking, and 9.7\% chose to give a warning. It was reported in the same study that, offending, embarrassing and punishing behaviors imposed on children, were likely to be the causes of serious future problems. Çelenk (2003) 
suggested that, the mental problems among children mainly arise from parental attitudes and the mistakes made in child-raising. Especially improper attitudes have negative impacts on the emotional-social and personal development of children that suffer from enuretic problems.

Conducted researches indicate that, enuresis among 6-12 year olds adversely affects the social relationships, school success and self-respect of the child, and also creates tension in parent-child relationship (Ünalan, 2000; Dönmez, 2004). Enuresis can be regarded as a problem that affects the social adaptation skills, domestic relationships, and overall mental health of the child. Therefore, early diagnosis and treatment of enuresis is a requisite in prevention of psychosocial problems (Toros et al. 2003; Yaluğ et al., 2006).

Nursing skills play an important role in early diagnosis of enuresis. Most of the foreign and domestic studies regarding enuresis have focused on the determination of bedwetting frequency, comparison of treatment alternatives and etiology, while no study was found on the definition and development of nursing attitudes towards enuretic children and parents in the health-care system (Çarman et al. 2003; Ergüven et al. 2004; Wen et al 2005; Demirören et al. 2006). Addressing the issue of parental attitudes towards enuretic children is considered to be helpful in treatment of enuretic children, as it is an important problem faced by children and their parents. This research was carried out in anticipation of contributing to the early diagnosis and treatment of enuresis.

\section{Objective of the Study}

The study was conducted to determine the parental attitudes towards children with and without enuresis in 7-12 age group.

\section{Study Population}

\section{Material And Method}

The population of this descriptive (case-control) research consist of total 11306 students receiving education in 28 primary schools in the provincial center of Tokat, and the mothers of these students. The sample of the study consist of a total of 280 people (140 case and 140 control) comprising the mothers of 140 enuretic students, and the mothers of 140 non-uretic children chosen (by their age, gender and class) as a control group for comparison purposes.

Sampling inclusion criteria: The children, resident in provincial center of Tokat, in the age group of 712 , voluntarily or involuntarily bedwetting, at least for six months, with a frequency of three consecutive months and twice a week, with no disease or medication related reason, and the mothers of these children were included in the sample.

\section{Data Collection Tools:}

Research data was collected using Parental Information form, and Parental Attitude Research Instrument (PARI) upon receiving written permissions from the related institutions.

Parental Information Form: This form involves total 24 questions defining the demographic properties (14 questions), family type and enuresis status (10 questions) of the children.

\section{Parental Attitude Research Instrument (PARI) :}

This scale was developed by Schaefer and Bell (1958) as a means to measure the child-rearing attitudes of parents, and its adaptation to Turkish language was made by Le Compte and Özer (references). In terms of reliability, Pearson Moment Product Correlation of the scale is between 0.58 and 0.88 . The scale includes 60 items, 5 dimensions and an assessment system with four scores. Scoring alternatives of the scale is as follows: "I do not approve at all" 1 point, "I barely approve" 2 points, "I quite approve" 3 points, and "I highly approve" 4 points. The total score of each sub-dimension indicates the level of the attitude represented by that specific dimension (Öner 1997).

\section{Data Evaluation:}

Evaluation of the data was carried out using SPSS 15.00 software package. Kolmogorov-Smirnov test, MannWhitney U test, Variance Analysis (ANOVA), Chi-Square Test, Arithmetic Mean (Ave.) and Standard Deviation (SD) calculations were used in data evaluation.

\section{Results}

In the group with enuretic children, $51.4 \%$ of the children were boys, $27.1 \%$ were 7 years old, $39.3 \%$ were the second child; and in the group with nonenuretic children, $51.4 \%$ were boys, $42.9 \%$ were the second child, and no statistically significant difference was found between the groups with respect to all variables ( $\mathrm{p}>$ 0.05 , Table 1). 
As seen in Table 2, in which the Identifying Properties of the Parents were compared, $36.4 \%$ of the mothers of enuretic children were under the age of 30, 35\% of fathers were in 36-40 age group, majority of the parents were primary school graduates, $94.3 \%$ of the mothers were unemployed, $40 \%$ of the fathers were selfemployed, $62.9 \%$ of the families were nuclear families and $55.7 \%$ were of a medium socioeconomic level. $32.9 \%$ of the mothers of nonenuretic children were in $31-35$ age group and $32.1 \%$ of the fathers were 41 or older, majority of the parents were primary school graduates, $95 \%$ of the mothers were unemployed and $47.9 \%$ of the fathers were self-employed, $65.7 \%$ were in a nuclear family, $63.9 \%$ of the parents were of a medium socioeconomic level and no statistically significant difference was found between the groups with respect to all variables $(\mathrm{p}>0.05)$.

As indicated in Table 3, in the PARI scale of all parents with and without enuretic children, the mean scores of all sub-dimensions except over-monitoring were at a medium level. PARI scale marital conflict subdimension of the parents with enuretic children had a higher mean score than the parents with nonuretic children, with a statistically significant difference $(\mathrm{p}<0.05)$.

As seen in Table 4, the five PARI subdimension mean scores of the mothers with enuretic children were found to be higher in the literate group, with respect to the educational status of mothers. A statistically significant difference $(\mathrm{p}<0.05)$ was found at the over-monitoring and severe discipline sub-dimensions, ,depending on the educational status of mother. With regard to the educational status of the mothers with enuretic children, all literate mothers with the exception of over-monitoring sub-dimension had higher scores. In the families with nonenuretic children, rejection of the role, marital conflict and severe discipline subdimensions exhibited a statistically significant difference with respect to mother's educational status $(p<0.05$; Table 4).

As indicated in Table 5 by the PARI sub-dimension means scores with respect to father's educational status, five sub-dimension mean scores of the fathers with and without enuretic children are higher in the literate group. Statistically significant difference $(\mathrm{p}<0.05)$ was found in the rejection of the role and marital conflict sub-dimensions, with respect to the educational status of fathers with enuretic children. Also, there is a statistically significant difference $(\mathrm{p}<0.05)$ in the severe discipline sub-dimension depending on the educational status of fathers with nonenuretic children.

PARI sub-dimension mean scores for the mother's educational status in enuretic group indicate that (Table 6) the mean scores are higher in five sub-dimensions in the unemployed group. In enuretic group, the marital conflict dimension of mother with regard to employment status, exhibits a statistically significant difference $(\mathrm{p}<0.05)$. In the group with nonenuretic children, PARI sub-dimension means scores depending on the mother's employment status indicate that the mean scores in five sub-dimensions of the unemployed group are higher. Statistically significant difference $(p<0.05)$ was found for the families with nonenuretic children in marital conflict and severe discipline dimensions, with respect to mother's employment status.

In a comparison of PARI subdimension mean scores of the group with enuretic children (Table 7), mean scores are higher in five subdimensions in the angry-punisher group. A statistically significant difference was found "in rejection of the role" subdimension of enuretic group $(\mathrm{p}<0.05)$.

\section{Tables}

Table 1. Distribution of the Identifying Properties of Enuretic and Nonenuretic Children $(n=280)$

\begin{tabular}{|c|c|c|c|c|c|c|c|}
\hline \multirow{2}{*}{\multicolumn{2}{|c|}{ Identifying properties }} & \multicolumn{2}{|c|}{ Enuretic $(n=140)$} & \multicolumn{2}{|c|}{ Non-enuretic $(n=140)$} & \multirow{2}{*}{ Test* $\chi^{2}$} & \multirow[b]{2}{*}{$\mathrm{p}$} \\
\hline & & $\mathrm{n}$ & $\%$ & $\mathrm{~N}$ & $\%$ & & \\
\hline \multirow{2}{*}{ Gender } & Girl & 68 & 48.6 & 68 & 48.6 & \multirow[b]{2}{*}{0.000} & \multirow[b]{2}{*}{1.000} \\
\hline & Boy & 72 & 51.4 & 72 & 51.4 & & \\
\hline \multirow{5}{*}{ Age } & 7 years & 38 & 27.1 & 38 & 27.1 & \multirow{5}{*}{0.413} & \multirow{5}{*}{0.995} \\
\hline & 8 years & 30 & 21.4 & 30 & 21.4 & & \\
\hline & 9 years & 28 & 20.0 & 26 & 18.6 & & \\
\hline & 10 years & 21 & 15.0 & 22 & 15.7 & & \\
\hline & 11-12 years & 23 & 16.4 & 24 & 17.1 & & \\
\hline \multirow{3}{*}{ Birth order } & 1. child & 51 & 36.4 & 38 & 27.1 & \multirow{3}{*}{2.958} & \multirow{3}{*}{0.228} \\
\hline & 2. child & 55 & 39.3 & 60 & 42.9 & & \\
\hline & 3rd or higher & 34 & 24.3 & 42 & 30.0 & & \\
\hline \multirow{3}{*}{$\begin{array}{l}\text { Number of } \\
\text { children }\end{array}$} & $1-2$ children & 60 & 42.9 & 57 & 40.7 & \multirow[b]{3}{*}{0.492} & \multirow[b]{3}{*}{0.782} \\
\hline & 3 children & 49 & 35.0 & 47 & 33.6 & & \\
\hline & $\begin{array}{l}4 \text { or more } \\
\text { children }\end{array}$ & 31 & 22.1 & 36 & 25.7 & & \\
\hline
\end{tabular}

*: Chi-square test 
Table 2. Distribution of the Identifying Properties of Enuretic and Nonenuretic Children's Parents $(\mathrm{n}=280)$

\begin{tabular}{|c|c|c|c|c|c|c|c|}
\hline \multicolumn{2}{|l|}{ Identifying properties } & \multicolumn{2}{|c|}{ Enuretic $(n=140)$} & \multicolumn{2}{|c|}{ Non-enuretic $(n=140)$} & \multirow{2}{*}{$\begin{array}{l}\text { Test* } \\
\chi^{2}\end{array}$} & \multirow[t]{2}{*}{$\mathrm{p}$} \\
\hline & & $\mathrm{n}$ & $\%$ & $\mathrm{~N}$ & $\%$ & & \\
\hline \multirow[t]{4}{*}{ Mother's age } & Under 30 & 51 & 36.4 & 44 & 31.4 & \multirow[t]{4}{*}{1.847} & \multirow[t]{4}{*}{0.605} \\
\hline & $31-35$ & 47 & 33.6 & 46 & 32.9 & & \\
\hline & $36-40$ & 27 & 19.3 & 36 & 25.7 & & \\
\hline & 41 and higher & 15 & 10.7 & 14 & 10.0 & & \\
\hline \multirow[t]{4}{*}{ Father's age } & Under 30 & 17 & 12.1 & 12 & 8.6 & \multirow[t]{4}{*}{4.027} & \multirow[t]{4}{*}{0.259} \\
\hline & $31-35$ & 43 & 30.7 & 41 & 29.3 & & \\
\hline & $36-40$ & 49 & 35.0 & 42 & 30.0 & & \\
\hline & 41 and higher & 31 & 22.1 & 45 & 32.1 & & \\
\hline \multirow{3}{*}{$\begin{array}{l}\text { Mother's educational } \\
\text { status }\end{array}$} & Literate & 15 & 10.7 & 16 & 11.4 & \multirow[t]{3}{*}{0.087} & \multirow[t]{3}{*}{0.957} \\
\hline & Primary school & 112 & 80.0 & 110 & 78.6 & & \\
\hline & High school and higher & 13 & 9.3 & 14 & 10.0 & & \\
\hline \multirow{3}{*}{$\begin{array}{l}\text { Fathers educational } \\
\text { status }\end{array}$} & Literate & 7 & 5 & 10 & 7.1 & \multirow[t]{3}{*}{2.704} & \multirow[t]{3}{*}{0.259} \\
\hline & Primary school & 110 & 78.6 & 98 & 70.0 & & \\
\hline & High school and higher & 23 & 16.4 & 32 & 22.9 & & \\
\hline \multirow{2}{*}{$\begin{array}{l}\text { Mother's employment } \\
\text { status }\end{array}$} & Unemployed & 132 & 94.3 & 133 & 95.0 & \multirow[t]{2}{*}{0.000} & \multirow[t]{2}{*}{1.000} \\
\hline & Employed & 8 & 5.7 & 7 & 5.0 & & \\
\hline \multirow{4}{*}{$\begin{array}{l}\text { Father's employment } \\
\text { status }\end{array}$} & Officer & 17 & 12.1 & 18 & 12.9 & \multirow[t]{4}{*}{2.791} & \multirow[t]{4}{*}{0.425} \\
\hline & Laborer & 47 & 33.6 & 42 & 30.0 & & \\
\hline & Self-employed & 56 & 40.0 & 67 & 47.9 & & \\
\hline & Tradesman & 20 & 14.3 & 13 & 9.3 & & \\
\hline \multirow[t]{3}{*}{ Family type } & Nuclear family & 88 & 62.9 & 92 & 65.7 & \multirow[t]{3}{*}{2.023} & \multirow[t]{3}{*}{0.364} \\
\hline & Extended family & 43 & 30.7 & 44 & 31.4 & & \\
\hline & Single parent & 9 & 6.4 & 4 & 2.9 & & \\
\hline \multirow[t]{3}{*}{ Economic condition } & Low & 43 & 30.7 & 28 & 20.5 & \multirow[t]{3}{*}{4.275} & \multirow[t]{3}{*}{0.118} \\
\hline & Medium & 78 & 55.7 & 89 & 63.9 & & \\
\hline & High & 19 & 13.6 & 23 & 16.4 & & \\
\hline
\end{tabular}

* Chi-square test

Table 3. Comparison of Mean PARI scores of The Parents of Enuretic and Nonenuretic Children

\begin{tabular}{|c|c|c|c|c|c|}
\hline \multirow{2}{*}{ (PARI) Dimensions } & \multirow{2}{*}{$\begin{array}{l}\text { Minimum and } \\
\text { Maximum } \\
\text { Scores }\end{array}$} & Enuretic $(\mathrm{n}=140)$ & Non-enuretic $(\mathrm{n}=140)$ & \multirow{2}{*}{$\begin{array}{c}\text { Test* } \\
\mathrm{t}\end{array}$} & \multirow[b]{2}{*}{$\mathrm{p}$} \\
\hline & & Average \pm SD & Average \pm SD & & \\
\hline Over-monitoring & $16-64$ & $53.54 \pm 7.15$ & $52.50 \pm 7.59$ & 1.174 & 0.241 \\
\hline Democratic & $9-36$ & $30.24 \pm 3.79$ & $30.39 \pm 4.08$ & -0.318 & 0.750 \\
\hline Rejection of role & $13-52$ & $27.38 \pm 5.78$ & $26.14 \pm 6.41$ & 1.702 & 0.090 \\
\hline Marital conflict & $6-24$ & $12.82 \pm 2.97$ & $11.95 \pm 3.60$ & 2.204 & 0.028 \\
\hline Severe discipline & $16-64$ & $43.32 \pm 7.51$ & $42.84 \pm 9.08$ & 0.480 & 0.632 \\
\hline
\end{tabular}

*: Test of significance of the variance between two means

Table 4. Comparison of PARI Scores of Mothers With and Without Enuretic Children With Regard to the Educational Status

\begin{tabular}{|c|c|c|c|c|c|c|c|}
\hline \multirow{2}{*}{$\begin{array}{l}\text { (PARI) } \\
\text { Dimensions }\end{array}$} & \multirow{2}{*}{$\begin{array}{l}\text { Educ. Statusof } \\
\text { Mother }\end{array}$} & \multicolumn{3}{|c|}{ Enuretic } & \multicolumn{3}{|c|}{ Non-Enuretic } \\
\hline & & Average \pm SD & Test*F & $\mathrm{P}$ & Average \pm SD & Test* F & $\mathrm{p}$ \\
\hline \multirow[t]{3}{*}{ Over-monitoring } & Literate & $55.86 \pm 7.87$ & \multirow[t]{3}{*}{3.796} & \multirow[t]{3}{*}{0.025} & $52.62 \pm 9.35$ & \multirow[t]{3}{*}{2.929} & \multirow[t]{3}{*}{0.057} \\
\hline & Primary school & $53.77 \pm 6.70$ & & & $53.07 \pm 7.21$ & & \\
\hline & $\begin{array}{l}\text { High school } \\
\text { and higher }\end{array}$ & $48.84 \pm 8.57$ & & & $47.92 \pm 7.33$ & & \\
\hline \multirow[t]{3}{*}{ Democratic } & Literate & $30.93 \pm 3.30$ & \multirow[t]{3}{*}{1.370} & \multirow[t]{3}{*}{0.257} & $30.56 \pm 3.40$ & \multirow[t]{3}{*}{0.139} & \multirow[t]{3}{*}{0.870} \\
\hline & Primary school & $30.24 \pm 3.95$ & & & $30.43 \pm 4.08$ & & \\
\hline & $\begin{array}{l}\text { High school } \\
\text { and higher }\end{array}$ & $28.69 \pm 2.49$ & & & $29.85 \pm 4.92$ & & \\
\hline \multirow[t]{3}{*}{ Rejection of role } & Literate & $28.60 \pm 5.64$ & \multirow[t]{3}{*}{1.182} & \multirow[t]{3}{*}{0.310} & $28.75 \pm 6.68$ & \multirow[t]{3}{*}{5.640} & \multirow[t]{3}{*}{0.004} \\
\hline & Primary school & $27.46 \pm 5.66$ & & & $26.37 \pm 6.35$ & & \\
\hline & $\begin{array}{l}\text { High school } \\
\text { and higher }\end{array}$ & $25.30 \pm 6.48$ & & & $21.35 \pm 4.01$ & & \\
\hline \multirow[t]{3}{*}{ Marital conflict } & Literate & $13.60 \pm 3.15$ & \multirow[t]{3}{*}{1.461} & \multirow[t]{3}{*}{0.235} & $12.68 \pm 3.53$ & \multirow[t]{3}{*}{4.856} & \multirow[t]{3}{*}{0.009} \\
\hline & Primary school & $12.84 \pm 2.96$ & & & $12.19 \pm 3.57$ & & \\
\hline & $\begin{array}{l}\text { High school } \\
\text { and higher }\end{array}$ & $11.69 \pm 2.75$ & & & $9.21 \pm 2.91$ & & \\
\hline \multirow[t]{3}{*}{ Severe discipline } & Literate & $47.40 \pm 7.71$ & \multirow[t]{3}{*}{7.334} & \multirow[t]{3}{*}{0.001} & $46.31 \pm 7.86$ & \multirow[t]{3}{*}{8.141} & \multirow[t]{3}{*}{0.001} \\
\hline & Primary school & $43.50 \pm 7.07$ & & & $43.40 \pm 8.92$ & & \\
\hline & $\begin{array}{l}\text { High school } \\
\text { and higher }\end{array}$ & $37.07 \pm 7.65$ & & & $34.42 \pm 7.07$ & & \\
\hline
\end{tabular}


Table 5. Comparison of PARI Scores of Fathers With and Without Enuretic Children With Regard to the Educational Status

\begin{tabular}{|c|c|c|c|c|c|c|c|}
\hline \multirow{2}{*}{$\begin{array}{l}\text { (PARI) } \\
\text { Dimensions }\end{array}$} & \multirow{2}{*}{$\begin{array}{lll}\text { Educ. } & \text { Status of } \\
\text { Father } & & \\
\end{array}$} & \multicolumn{3}{|c|}{ Enuretic } & \multicolumn{3}{|c|}{ Non-Enuretic } \\
\hline & & Average \pm SD & Test* F & $\mathrm{P}$ & Average \pm SD & Test* F & $\mathrm{p}$ \\
\hline \multirow{3}{*}{$\begin{array}{l}\text { Over- } \\
\text { monitoring }\end{array}$} & Literate & $56.00 \pm 8.96$ & \multirow[t]{3}{*}{0.477} & \multirow[t]{3}{*}{0.622} & $53.70 \pm 9.52$ & \multirow[t]{3}{*}{1.680} & \multirow[t]{3}{*}{0.190} \\
\hline & Primary school & $53.50 \pm 7.25$ & & & $53.08 \pm 7.45$ & & \\
\hline & $\begin{array}{l}\text { High school and } \\
\text { higher }\end{array}$ & $53.00 \pm 6.22$ & & & $50.37 \pm 7.22$ & & \\
\hline \multirow[t]{3}{*}{ Democratic } & Literate & $31.28 \pm 2.75$ & \multirow[t]{3}{*}{0.469} & \multirow[t]{3}{*}{0.627} & $31.60 \pm 3.89$ & \multirow[t]{3}{*}{1.108} & \multirow[t]{3}{*}{0.333} \\
\hline & Primary school & $30.28 \pm 4.02$ & & & $30.53 \pm 4.22$ & & \\
\hline & $\begin{array}{l}\text { High school and } \\
\text { higher }\end{array}$ & $29.73 \pm 2.86$ & & & $29.59 \pm 3.65$ & & \\
\hline \multirow{3}{*}{$\begin{array}{l}\text { Rejection of } \\
\text { role }\end{array}$} & Literate & $30.85 \pm 4.41$ & \multirow[t]{3}{*}{3.459} & \multirow[t]{3}{*}{0.034} & $27.50 \pm 7.24$ & \multirow[t]{3}{*}{1.141} & \multirow[t]{3}{*}{0.322} \\
\hline & Primary school & $27.66 \pm 5.69$ & & & $26.46 \pm 6.52$ & & \\
\hline & $\begin{array}{l}\text { High school and } \\
\text { higher }\end{array}$ & $25.00 \pm 5.95$ & & & $24.71 \pm 5.74$ & & \\
\hline \multirow{3}{*}{$\begin{array}{l}\text { Marital } \\
\text { conflict }\end{array}$} & Literate & $13.42 \pm 4.03$ & \multirow[t]{3}{*}{9.583} & \multirow[t]{3}{*}{0.001} & $12.30 \pm 4.32$ & \multirow[t]{3}{*}{2.337} & \multirow[t]{3}{*}{0.100} \\
\hline & Primary school & $13.27 \pm 2.72$ & & & $12.30 \pm 3.61$ & & \\
\hline & 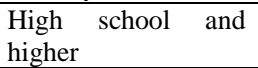 & $10.47 \pm 2.81$ & & & $10.75 \pm 3.17$ & & \\
\hline \multirow{3}{*}{$\begin{array}{l}\text { Severe } \\
\text { discipline }\end{array}$} & Literate & $48.28 \pm 7.49$ & \multirow[t]{3}{*}{2.536} & \multirow[t]{3}{*}{0.083} & $44.70 \pm 9.42$ & \multirow[t]{3}{*}{8.845} & \multirow[t]{3}{*}{0.001} \\
\hline & Primary school & $43.45 \pm 7.65$ & & & $44.48 \pm 8.70$ & & \\
\hline & $\begin{array}{l}\text { High school and } \\
\text { higher }\end{array}$ & $41.17 \pm 6.22$ & & & $37.21 \pm 8.07$ & & \\
\hline
\end{tabular}

F: ANOVA

Table 5. Comparison of PARI Scores of Mothers With and Without Enuretic Children With Regard to the Employment Status

\begin{tabular}{|c|c|c|c|c|c|c|c|}
\hline \multirow{2}{*}{$\begin{array}{l}\text { (PARI) } \\
\text { Dimensions }\end{array}$} & \multirow{2}{*}{$\begin{array}{l}\text { Mother's } \\
\text { educational } \\
\text { status }\end{array}$} & \multicolumn{3}{|c|}{ Enuretic } & \multicolumn{3}{|c|}{ Non-enuretic } \\
\hline & & Average \pm SD & Test $* U$ & $\mathrm{P}$ & Average \pm SD & Test $* U$ & $\mathrm{p}$ \\
\hline \multirow{2}{*}{ Over-monitoring } & Unemployed & $53.68 \pm 7.13$ & \multirow[t]{2}{*}{426.5} & \multirow[t]{2}{*}{0.361} & $52.73 \pm 7.62$ & \multirow[t]{2}{*}{283.0} & \multirow[t]{2}{*}{0.081} \\
\hline & Employed & $51.12 \pm 7.51$ & & & $48.14 \pm 5.75$ & & \\
\hline \multirow[t]{2}{*}{ Democratic } & Unemployed & $30.30 \pm 3.84$ & \multirow[t]{2}{*}{434.0} & \multirow[t]{2}{*}{0.397} & $30.48 \pm 4.09$ & \multirow[t]{2}{*}{331.5} & \multirow[t]{2}{*}{0.198} \\
\hline & Employed & $29.25 \pm 2.81$ & & & $28.71 \pm 3.77$ & & \\
\hline \multirow{2}{*}{$\begin{array}{l}\text { Rejection of the } \\
\text { role }\end{array}$} & Unemployed & $27.41 \pm 5.69$ & \multirow[t]{2}{*}{523.5} & \multirow[t]{2}{*}{0.968} & $26.24 \pm 6.42$ & \multirow[t]{2}{*}{363.0} & \multirow[t]{2}{*}{0.326} \\
\hline & Employed & $26.87 \pm 7.58$ & & & $24.14 \pm 6.36$ & & \\
\hline \multirow[t]{2}{*}{ Marital conflict } & Unemployed & $12.96 \pm 2.98$ & \multirow[t]{2}{*}{234.5} & \multirow[t]{2}{*}{0.008} & $12.09 \pm 3.59$ & \multirow[t]{2}{*}{239.5} & \multirow[t]{2}{*}{$\mathbf{0 . 0 3 0}$} \\
\hline & Employed & $10.37 \pm 1.40$ & & & $9.14 \pm 2.67$ & & \\
\hline \multirow[t]{2}{*}{ Severe discipline } & Unemployed & $43.57 \pm 7.41$ & \multirow[t]{2}{*}{399.0} & \multirow[t]{2}{*}{0.246} & $43.27 \pm 8.88$ & \multirow[t]{2}{*}{226.5} & \multirow[t]{2}{*}{0.022} \\
\hline & Employed & $39.12 \pm 8.44$ & & & $34.57 \pm 9.62$ & & \\
\hline
\end{tabular}

U: Mann-Whitney U Test

Table 7. Comparison of PARI Scores Based on the Responses of Parents to Their Enuretic Children.

\begin{tabular}{|c|c|c|c|c|c|}
\hline $\begin{array}{l}\text { (PARI) } \\
\text { Dimensions }\end{array}$ & Responses to Children & n (140) & Average \pm SD & Test * F & $\mathrm{p}$ \\
\hline \multirow{3}{*}{ Over-monitoring } & Behaving well & 87 & $53.59 \pm 6.70$ & \multirow[t]{3}{*}{1.626} & \multirow[t]{3}{*}{0.201} \\
\hline & Getting angry-punishing & 30 & $55.00 \pm 6.49$ & & \\
\hline & Communicating-Explaining & 21 & $51.33 \pm 9.54$ & & \\
\hline \multirow[t]{3}{*}{ Democratic } & Behaving well & 89 & $29.71 \pm 34.01$ & \multirow[t]{3}{*}{3.709} & \multirow[t]{3}{*}{0.027} \\
\hline & Getting angry-punishing & 30 & $31.83 \pm 2.78$ & & \\
\hline & Communicating-Explaining & 21 & $29.90 \pm 3.59$ & & \\
\hline \multirow[t]{3}{*}{ Rejection of the role } & Behaving well & 89 & $26.82 \pm 5.61$ & \multirow[t]{3}{*}{5.867} & \multirow[t]{3}{*}{0.004} \\
\hline & Getting angry-punishing & 30 & $30.33 \pm 6.03$ & & \\
\hline & Communicating-Explaining & 21 & $25.42 \pm 4.83$ & & \\
\hline \multirow[t]{3}{*}{ Marital conflict } & Behaving well & 89 & $12.36 \pm 3.04$ & \multirow[t]{3}{*}{2.847} & \multirow[t]{3}{*}{0.062} \\
\hline & Getting angry-punishing & 30 & $13.66 \pm 2.61$ & & \\
\hline & Communicating-Explaining & 21 & $13.52 \pm 3.01$ & & \\
\hline \multirow[t]{3}{*}{ Severe Discipline } & Behaving well & 89 & $43.37 \pm 7.54$ & \multirow[t]{3}{*}{1.269} & \multirow[t]{3}{*}{0.284} \\
\hline & Getting angry-punishing & 30 & $44.60 \pm 7.36$ & & \\
\hline & Communicating-Explaining & 21 & $41.19 \pm 7.83$ & & \\
\hline
\end{tabular}

*: ANOVA 


\section{Conclusion}

Parental attitudes play an important role in personal development of children and in equipping them with positive social behaviors. Problematic behaviors such as enuresis may be exhibited by children depending on the child-rearing attitudes of parents. According to the obtained results, $48.6 \%$ of the girls and $51.4 \%$ of the boys suffered from enuresis and average age of the both groups was 7. In their study Hazza et al. (2002) reported that $33.7 \%$ of the girls and $15.7 \%$ of the boys were enuretic. According to the results of Swithinbank's (1994) research, conducted in England, 6\% of the girls and 4\% of the boys were enuretic, whereas Watanabe's study (1995) carried out in Japan showed that $10 \%$ of the girls and $8 \%$ of the boys were facing enuresis. In Turkey, Top and Küçük (2014) reported the enuresis frequency as $53.1 \%$ for the girls and $46.9 \%$ for the boys. Even though incidence rate of enuresis is observed at higher rates among girls, its prevalence among boys is supported in the literature (Bolat et al., 2013; Özçetin et al., 2010; Karataş and Keleş, 2005).

In the present study, $36.4 \%$ of the mothers of enuretic children were under the age of 30 , and $35 \%$ of the fathers were between 36-40. In Hizel's (1990) study, 44.4\% of mothers were reported to be over the age of 30, and in Şahin's (2000) study in Erzurum, 70.6\% of mothers with enuretic children were reported to have an average age of $33.3 \pm 5.4$. In this study, $80 \%$ of the mothers, and $78.6 \%$ of fathers with enuretic children were primary school graduates. According to Bolat et al. (2013), the risk of enuresis was 5.73 times higher for children of illiterate mothers and 1.91 times higher for primary school graduates. This rate also supports the results of our study.

In this study, majority of the mothers with and without enuretic children were housewives. In the study carried out by Kizil (2002) in Trabzon and in Sahin's (2000) study, respectively $23.3 \%$ and $86.3 \%$ of the mothers with enuretic children were reported to be housewives. The results of these studies and the present study indicate that children of unemployed mothers were facing the problem of enuresis at higher rates. Prevalence of enuresis among the children with unemployed mothers is attributed to mothers' sparing more time to house works, thus failing to pay enough attention to their children.

In this work, majority of enuretic and nonenuretic children were found to be living in a nuclear family (\%62.9-\%65.7). In Bahtiyar's (1993) study $77.3 \%$ of enuresis cases and in the study of Ünalan et al. (2001) $21 \%$ of enuresis cases were diagnosed in nuclear families. Şahin et al. (2001) found that enuresis was diagnosed in $15.5 \%$ of nuclear families, $9.4 \%$ of extended families, and $25 \%$ of fragmented families. In the present study, no significant relationship was found between family structure and enuresis, whereas a high rate of incidence was found among nuclear families. This can be ascribed to the limited research area (Tokat provincial center) and omission of extended families in rural areas.

In the present research, economic levels of both groups were found to be at a medium socioeconomic level (\%55.7-\%63.9). Insufficient stimulus in home environment, parental negligence attitudes and exposure to chronic violence are closely related with socio economic levels of families, which can have a significant impact on the mental development of the child (Aber, 2000). As the parents with low socioeconomic levels deal with more problems, they are more likely to be unaware of the physical and psychological requirements of their children, thus failing to pay enough attention for this particular issue.

Yavuzer (2004) also reported that, middle aged and older parents exhibited either over-monitoring or over-negligent attitudes towards their children. Marital conflicts that take place in family environments, inconsiderateness of husband and his reluctance in helping the wife can induce various domestic issues which may lead to serious psychological problems among children, as in the case of enuresis among children. In this study, high rates of marital conflict dimension among enuretic children can be attributed to this factor. In their study, Büküsşoğlu et al. (2001) reported that mental indications among mothers and problematic attitudes of children tend to increase upon reflection of the marital conflict among parents on their parental functions. Hizel (1999) and Güven (1990) reported that, the parents resorted to over-monitoring and oppressive discipline attitudes, while no significant difference was found between enuretic and nonenuretic groups in comparison of parental attitude scales. In the present study, high rates of over-monitoring attitudes among enuretic and nonenuretic groups can be ascribed to majority of mothers' being middle-aged women.

In enuretic group, mothers were found to have over-monitoring and severe discipline attitudes, whereas in nonenuretic group mothers were found to have rejection of the role, marital conflict and severe discipline attitudes ( $\mathrm{p}<0.05)$. Ulusoy et al (2006) reported that, $38.1 \%$ of competent-kindly firm mothers were secondary school graduates, $44.6 \%$ of oppressive-dominating mothers were primary school graduates, and $45.2 \%$ of permissive-tolerant mothers were faculty or higher education graduates. $68.2 \%$ of permissive-negligent mothers were primary school graduates. The results show that the majority of oppressive-dominating and permissivenegligent mothers are primary school graduates. In the present research, low educational levels resulted in increased severe discipline and monitoring attitudes, which is in agreement with other researches in the literature.

In this work, the fathers have rejection of the role and marital conflict attitudes in enuretic group, and severe discipline attitude in the nonenuretic group. Ulusoy et al. reported that, 55.3\% of the competent-kindly 
firm fathers, $35.1 \%$ of oppressive-dominating fathers, $58.5 \%$ of permissive-tolerant fathers and only $28 \%$ of permissive-negligent fathers were faculty or higher education graduates. According to these results, graduation rate of oppressive-dominating and permissive-negligent fathers from faculties or higher education institutions is significantly low. Father's unhealthy interaction with his own parents, and the lovelessness and oppression that he suffered in his childhood period, can be the underlying reason for such negative attitudes towards his child.

Marital conflict attitude was detected in enuretic group, marital conflict and severe discipline attitudes were detected in the nonenuretic group, depending on the mother's employment status $(\mathrm{p}<0.05)$. Unemployed mothers were found to spare more time and energy for the physical care and discipline of their children compared to employed mothers, and their being present at home throughout the day with their children brings about the notion that mother-child relationship in these families are more apt to deteriorate. In addition, economic troubles of unemployed mothers bring about various problems which has negative impacts on motherchild relationship (Aktaş 1994).

In line with the response of the parents to their children, a statistically significant difference was found in enuretic group with regard to the parents' "rejection of the role" attitude $(\mathrm{p}<0.05)$. Karataş and Keleş $(2005)$ also reported in their study that $55.3 \%$ of the mothers responded to their children in anger, which is in agreement with the findings of the present study.

\section{Conclusion and Recommendations}

High levels of marital conflict attitude was detected in both enuretic and nonenuretic groups. For more accurate results, further studies on family attitudes likely to cause enuresis in different areas, and evaluation of socioeconomic, cultural and other factors as other causes of enuresis beside family attitudes, are recommended for obtaining more accurate results.

\section{References}

[1]. Aber Jl, Jones S, Cohen S (2000) The İmpact of Poverty on the Mental Health and Development of Very Young Children, Ch Zeanah (Ed), Handbook Of Infant Mental Health, New York, Guildford Pres P,113-125.

[2]. Aktaş Y (1994) Çalışan Anne ve Çocuğu, Yaşadıkça Eğitim, 36: 7-11.

[3]. Bahtiyar S (1993) İstanbul Șişli İlçesi 1992 Yılı İlk-Orta Öğrenim Okullarında, 6-12 Yaş Grubu Çocuklarda Enürezis Prevalansı ve Nedenlerinin Araştırılması, Uzmanlık Tezi, İstanbul, Sağlık Bakanlığı.

[4]. Berber S (1990) Sosyo-Ekonomik Faktörlerin ve Ana-Baba Tutumlarının Okul Başarısına Etkisi, Yayınlanmamış Yüksek Lisans Tezi, Ankara, Gazi Üniversitesi

[5]. Bolat D, Ersin Zümrütbaş A, Cenk Acar İ, Burak Sancak E, Eskiçorapçı S, Zencir M, Turan T, Sınık Z (2013) Deniz İlinde İlköğretim Cağındaki Çocuklarda Nokturnal Enürezis Prevalansı ve Risk Faktörleri, Pamuk kale Araștırma Dergisi,6(2):82-90

[6]. Butler R (1998) Night Wetting in Children: Psychological Aspect. J Child Psychol Psychiatry, 39, 453-463.

[7]. Büküşoğlu N, Aysan F, Erermiş S (2001) Okul Fobisi Olan Çocukların Davranışsal Özellikleri, Annelerinin Ruhsal Belirti Düzeyleri ve Aile Fonksiyonlarının İncelenmesi, Ege Tıp Dergisi 40 (2): 99 - 104.

[8]. Çetinkaya B, Başbakkal Z (2005) Çocuk Sağlığı ve Hastalıkları Kliniklerinde Çalışan Hemşirelerin Benlik Saygısı Düzeylerinin ve Çocuk Yetiştirme Tutumlarının İncelenmesi, Ege Üniversitesi Hemşirelik Yüksekokulu Dergisi, 21(2): 47-57.

[9]. Çelenk S (2003) Okul Başarısının Ön Koşulu Okul-Aile Dayanışması, İlköğretim Online Dergisi, 2(2) : 28-34.

[10]. Demiriz S, Öğretir A.D (2007) Alt ve Üst Sosyo-eko nomik Düzeydeki 10 Yaş Çocuklarının Anne Tutumlarının İncelenmesi, Kastamonu Eğitim Dergisi 15(1): 105-122

[11]. Dönmez O (2004) Çocuklarda Nokturnal Enürezis, Güncel Pediatri Dergisi, 2: 134-136.

[12]. Erkan S, Toran M (2004) Alt Sosyoekonomik Düzey Annelerin Çocuklarını Kabul ve Reddetme Davranışlarının İncelenmesi, Hacet tepe Üniversitesi Eğitim Fakültesi Dergisi, 27:91-97.

[13]. Ertan P, Karaboğa B (2012) Monosemptomatik Nokturnal Enürezis , Dicle Tıp Dergisi , 39(1): 145-152

[14]. Genç H (1994) Psişik Enürezisli Çocuklarda Ailenin Yapı Tutum Davranış Ve Yaklaşımlarının İncelenmesi, Yüksek Lisans Tezi, İzmir, Ege Üniversitesi.

[15]. Hızel M (1990) Okul Çocuklarında (7-12 Yaş ) Görülen Enürezis ve Enkoprezis Sıklığının Aile Tutumu İle İlişkisi, Yüksek Lisans Tezi, İstanbul, İstanbul Üniversitesi.

[16]. Kızıl M (2002) Trabzon İl Merkezinde Enürezis Prevelan sı ve Risk Faktörlerinin Belirlenmesi, Yüksek Lisans Tezi, Trabzon, Karadeniz Teknik Üniversitesi.

[17]. Küçük L (2009) Çocuk ve Ergenlerde Önemli Bir sorun Olan Enürezisin Psikososyal Yönü, IV. Ulusal Ürijinekoloji Kongresinde

[18]. Kürtüncü M, Alkan I (2016) 6-12 Yaș Grubu Çocuklarda Enürezis Nokturna Prevalansı ve İlișkili Faktörler , Electronic - Journal of Vocational Colleges, 33-36

[19]. Öner N (1997) Türkiyede Kullanılan Psikolojik Testler, Boğaziçi Üniversitesi Eğitim Fakültesi, Boğaziçi Üniversitesi Matbası, İstanbul.

[20]. Sipahioğlu Ş (1990) Ana-Baba Tutumları ile Çocuklarda ki Problem Davranışlar Arasındaki İlişkinin İncelenmesi, Yayınlanmamış Yüksek Lisans Tezi, Ankara, Ankara Üniversitesi.

[21]. Şahin O (2000) Erzurum İl Merkezi İlkokul Birinci Sınıf Öğrencilerinde Enürezis Sıklığı ve Etkileyen Faktörler, Yüksek Lisans Tezi, Erzurum, Atatürk Üniversitesi.

[22]. Uluocak N, Erdemir F (2011) Enurezis Noturna Etiyopatogenez, Tur Üroloji Semineri, 2:35-40

[23]. Ulusoy M.D, Demir N.Ö, Baran A.G (2005) Ebeveynin Çocuk Yetiştirme Biçimi ve Ergen Problemleri Ankara İli Örneği, Hacette pe Üniversitesi Edebiyat Fakültesi Sosyoloji Bölümü, Ankara

[24]. Ünalan D (2000) Kayseri Kentsel Kesimde 7-12 Yaş Grubu Çocukların Enürezis Nokturna, Kekemelik ve Tik Görülme Sıklı̆̆ı, Yüksek Lisans Tezi, Kayseri, Erciyes Üniversitesi.

[25]. Tapçan K.T (2002) Ebeveyn Tutumları İle İlköğretim 6-7 Sınıf ve 8. Sınıf Öğrencilerinin Denetim Odağı İlișkisi, Yüksek Lisans Tezi, Balıkesir, Balıkesir Üniversitesi. 
[26]. Top Üstüner F, Küçük Alemdar D (2014) 7-11 Yaş Arası Çocuklarda Enürezis Sıklığı ve Risk Faktörleri, Gümüşhane Üniversitesi Sağlık Bilimleri Dergisi, 3(4) 991-1000

[27]. Toros F, Tot Ş, Bozlu M, Okyay Y, Çamdeviren H (2003) Dikkat Eksikliği Hiperaktivite Bozukluğu ve Primer Enürezis Nokturnal Çocukların Annelerindeki Psikiyatrik Belirtiler ve Yeti Yitimi, Klinik Psikiyatri; 6:135-140

[28]. Yaluğ İ, Ünsalan N, Özten E, Öztep Kuruoğlu S, Tufan A.E (2006) Erișkinde İkincil Enürezis Nokturna: Bir Olgu Sunumu, Anadolu Psikiyatri Dergisi, 7:185- 190.

[29]. Yavuzer H (2004) Cocuk Eğitimi El Kitabı, Remzi Kitabevi, İstanbul, S.39-86

[30]. Yutbay T, Görker I (2004) Çocukluk Masturbasyonu Olgularının Duygusal ve Davranış Sorunları ile Annelerin Tutum Ruhsal Belirtileri Arasındaki İlişki, Çocuk ve Gençlik Ruh Sağlığı Dergisi, 11(2): 65-74. 